\title{
Implementation of Authentic Assessment in Thematic Learning 2013 Curric- ulum at Madrasah Ibtidaiyah
}

\author{
Inayati Huda *, Wahyu, Karyono Ibnu Ahmad \\ Master Program of Education Management, Universitas Lambung Mangkurat, Banjarmasin 70123, \\ Indonesia
}

Article history:

Submission September

2020

Revised December 2020

Accepted December

2020

${ }^{*}$ Corresponding author:

E-mail:

ainani.huda@gmail.com

\begin{abstract}
This study aimed to describe the implementation of authentic thematic learning assessments in the 2013 curriculum of the Ibtidaiyah Public Madrasah and Private Ibtidaiyah Madrasah and their constraints and solutions. This research is a descriptive study with a qualitative approach. The results showed that: Teacher MIN 14 Banjar and MIS Nur Rahman Banjar District had carried out authentic assessments well in thematic learning Curriculum 13 because the assessment was carried out on aspects of attitude, knowledge, and skills assessment. Constraints encountered, namely: limited time constraints, more costs, the number of components/criteria in authentic assessment, the lack of student motivation in participating in innovative learning with authentic assessment, and the facilities and infrastructure of madrasas are still limited. The solution to overcoming obstacles is by forming groups of teachers in which they are devoted to discussing authentic assessment planning.
\end{abstract}

Keywords: Authentic assessment, learning, thematic, 2013 Curriculum

\section{Introduction}

The use of authentic assessment already exists in the Education Level Unit Curriculum (KTSP) which emphasizes the achievement of competencies to do everything according to the characteristics of each subject. Then more emphasized or become the main characteristics in the 2013 Curriculum, because it has strong relevance to the scientific approach to learning following the demands of the 2013 Curriculum. The 2013 Curriculum is a new curriculum that serves as a complement to the previous curriculum. The important part of the curriculum is the curriculum knowledge, which can be comprised of three activities, which are planning, implementing, and evaluating (Beuchamp, 1961). The curriculum is also seen divided into theory, design, and change (Foshay \& Beilin, 1969). Meanwhile, Rosales-Dordelly \& Short (1985) have created a conceptual framework and identified eight areas of the field including policy-making, development and evaluation, change and enactment, decision making, the field of study or activity, forms of inquiry, languages for inquiry, and questions directing activity. Whereas, the technical aspects of curriculum construction, including the development and curriculum design, are the only agreed upon domains (Ornstein, 1993). Thus, as part of defining professional standards and establishing the accountability measures is integral to make an effective school reform (Behar, 1994) to make students need to be able to connect academic learning explicitly with the areas of knowledge, skills, and approaches needed both for professional work and for lifelong learning (Fung, 2017).

Authentic assessment can describe the improvement of student learning outcomes, in the context of observing, reasoning, experimenting, building networks, and so on. The student learning outcomes can be an indicator of education quality (Kanjee, 2013). Meanwhile, the

\section{How to cite:}

Huda, I. (2020). Implementation of authentic assessment in thematic learning 2013 curriculum at Madrasah Ibtidaiyah. Journal of K6 Education and Management, 3 (4), 456 - 466. doi: 10.11594/jk6em.03.04.05 
assessment plays a fundamental part in understanding a child holistically (Green, 2019). Authentic assessments are not intended to replace traditional judgments. But, it is to complement each other and cover the shortcomings of objective assessment. Assessment in all its dimension is a contested idea (Osman, 2013). The assessment measures can be used effectively to prevent, identify, and address barriers of learning and development (Amod \& Heafield, 2013) and also contribute to give feedback to the students on their learning and as the certification of their achievement (Boud \& Falchikov, 2006). Whereas, the assessment itself can be considered as a systemic process of making judgments, and consequently reporting results (Laborda et al., 2015).

Authentic assessment is important in formal and informal learning (Santos, Cook, \& Hernandez-Leo, 2015). This authentic assessment aims to evaluate students' abilities in a realworld context. In other words, students learn how to apply their knowledge and skills to authentic assignments. Through this authentic assessment, it is hoped that a variety of valid/correct and accurate information can be netted about what students know and can do about the quality of educational programs. It is in line with Brown, Collins, \& Duguid (1989) who have defined authentic or situated learning as the perspective of social constructivism that occurs when the learner takes part in relevant activities to her real life and which take place within a culture similar to an applied context. This is quite different compared to the current educational and professional curriculum that is more focused on the development of competences (Gulikers et al., 2004).

Authentic assessment is developed because traditional assessments that have been used ignore the real-world context and do not describe students' abilities holistically (Santrock, 2017) and as a result of criticism of multiplechoice tests which usually only provide a superficial idea of what has been learned by students which do not indicate what can be done by them with what has been required (Aiken, 1996). Authentic assessment is said to be an alternative assessment because it can be used as an alternative to replace traditional assessments. For instance, nowadays, there are web- based courses that using the authentic assessment system that including online forums, online tests, self-evaluation, and the assessment of e-learner processes and products by a tutor, peers, and an expert (Olfos \& Zulantay, 2007). From this example, it can be seen that authentic assessment happens within the context of an authentic activity with multifaceted challenges and centers on an active learner that produces advanced results or products (Herrington \& Herrington, 1998) which is including the tests and projects development (Condemarin \& Medina, 2000).

That is why, authentic assessments tend to focus on complex or contextual tasks, enabling students to demonstrate their competence in more authentic settings. Authentic assessment is very relevant to integrate thematic approaches in learning, especially at the elementary school level or for appropriate subjects. It becomes possible as the learning process has been more authentic and educationally entertaining with the help of advanced technology (Shadiev et al., 2017; Dalle \& Mutalib, 2018). Thus, learning can be more attractive, effective, and meaningful (Kiernan \& Aizawa, 2004). Based on this fact, creating a new learning environment is part of the authentic assessmentbased-curriculum (Shadiev et al., 2018). According to (2016) argues that "the 2013 curriculum reinforces the shift in conducting assessments, namely from assessment through tests (based on results only), to authentic assessments (measuring attitudes, skills, and knowledge-based on processes and results)". This assessment can describe the increase in student learning outcomes, both in the context of observing reasoning, trying, and building networks.

Research on authentic assessment in schools is a research activity that has been carried out by previous researchers, including research by Aiman (2015), which revealed that the implementation of the authentic 2013 curriculum assessment in $M$ has not been fully implemented following the authentic assessment process procedure and has not entirely used instruments that are following the authentic assessment procedure. Budiarti (2015) revealed that the MI teachers had understood the basic 
concepts of authentic assessment, but in the application, they could not apply and adapt to the demands of the 2013 curriculum, the assessment was still carried out in groups, not individually so that authentic assessments which were a characteristic feature of the 2013 curriculum had not run optimally.

This authentic assessment must be understood in depth by teachers considering that every measurement of student competence is not enough with objective tests alone, because these tests cannot show all the competencies that students have mastered. Authentic assessment is a directly meaningful assessment, in the sense that what is being assessed is something that students need in real-life every day. Teachers still have many difficulties in implementing authentic assessment in thematic learning. It is because enhancing practice to offer students a greater opportunity to develop both skills and disciplinary knowledge in a supported and challenging environment (Kneale \& Collings, 2015) is not easy. Hence, innovation and good practice should not be limited by the regulations, but instead, regulations should serve student learning (Kneale \& Collings, 2018). Moreover, Madrasah Ibtidaiyah has more Islamic religious subjects compared to elementary schools, so teachers find it difficult to be able to link themes to these subjects.

In the Banjar Regency area, especially in the Martapura sub-district, 11 Madrasah Ibtidaiyah are consisting of 2 State Madrasah Ibtidaiyah and 9 Private Madrasah Ibtidaiyah which are under the auspices of the Ministry of Religion of Banjar Regency. At the Madrasah Ibtidaiyah (MI) level, the 2013 curriculum began to be applied in grades I and IV, by applying graduate competency standards, content, processes, and assessments that were adjusted to the 2013 curriculum. Meanwhile, several other classes still applied to KTSP. At Madrasah Ibtidaiyah Negeri 14 Banjar, the 2013 Thematic Learning Curriculum has been implemented in all classes, but at Private Madrasah Ibtidaiyah still not implementing the Thematic Learning 2013 Curriculum as a whole.

In Madrasah Ibtidaiyah Nur Rahman only implemented certain classes, especially the lower classes. In contrast to Public Madrasah
Ibtidaiyah, Private Madrasah Ibtidaiyah still have limitations and problems in optimizing the implementation of the 2013 Curriculum for Authentic Assessment in Thematic Learning.

\section{Material and Methods}

Research on the Implementation of Authentic Assessment in Thematic Learning of the 2013 Curriculum uses a qualitative approach with the type of case research at MIN 14 Banjar and MIS Nur Rahman in Banjar Regency. The methods of qualitative approach including interviews and focus group, also participant observation which has the function to gain insight into the processes involved in certain phenomenon or lived experiences, cultural ritual/habits, etc (Atkinson, 2017).

The data in this study include primary data and secondary data. Primary data is obtained through interviews and observations, while secondary data is obtained through documentation. The data analysis in this study consisted of single site data analysis and multi-site data analysis. The analysis is done by describing the data elaborately.

\section{Results and Discussion Implementation of authentic thematic learn- ing assessment in the 2013 curriculum at MIN 14 Banjar and MIS Nur Rahman Banjar Regency}

This study is intended to determine the description of the implementation of authentic thematic learning assessment in the 2013 curriculum at MIN 14 Banjar and MIS Nur Rahman Banjar Regency. The results of measuring the level of implementation of authentic thematic learning assessments in the 2013 curriculum at MIN 14 Banjar and MIS Nur Rahman Banjar Regency are based on educational assessment standards for each observed aspect (planning, implementation, analysis and reporting, attitude assessment techniques and instruments, techniques, and instruments). assessment of knowledge and techniques and skills assessment instruments).

There are 3 (three) things that are the main components of the implementation of this authentic assessment: namely (1) attitude competency assessment in thematic learning, (2) 
knowledge competency assessment in thematic learning, (3) skills competency assessment in thematic learning.

Authentic assessments carried out by teachers at MIN 14 Banjar and MIS Nur Rahman are following the authentic assessment model according to the Ministry of Education and Culture (Kusmijati, 2014) including performance appraisals, project assessments, portfolio assessments, and written assessments that are applied based on skill domains. the realm of attitudes and the realm of knowledge. Based on the description above, it can be concluded that in the knowledge competency assessment, both MIN 14 Banjar teachers and MIS Nur Rahman teachers, Banjar Regency both use 3 types of assessment, namely written tests, oral tests, and assignments. In its implementation, it is adjusted to the planning that has been made previously. Also, MIN 14 Banjar teachers often add exercises to deepen the material contained in student books.

From the documentation, many teachers do not have an attitude assessment sheet that should be attached to the lesson plan. Some teachers only take thorough hand notes in conducting attitude assessments. These results are also supported by the results of interviews which state that the teacher can't observe in detail the various types of attitudes to assess each student so that the teacher only makes notes on the overall attitudes such as the best, the best, the best, the discipline, the laziest and so on.

Even so, every teacher from MIN 14 Banjar or MIS Nur Rahman Banjar Regency tries to complete every instrument needed in implementing authentic thematic learning assessments (Enggarwati, 2015) that they do in their respective classes.

From the observations of several teachers of MIN 14 Banjar and MIS Nur Rahman, Banjar Regency, they have indeed carried out a written test or an oral test following the demands of the Minister of Education and Culture, such as tests, UAS, UN, and others. But written tests or other oral tests such as making quizzes, tests at the beginning of learning or the end of learning, and so on are rarely done, this is due to lack of preparation and limited time in class.

The implementation level of authentic assessment at MIN 14 Banjar is better than MIS
Nur Rahman Banjar Regency. In obtaining the highest average score, MIN 14 Banjar is in a good category. Then, when viewed from the observed aspects, MIN 14 Banjar is more dominant in the implementation aspect, while for the technical aspects and the attitude and knowledge assessment instruments, the percentage of implementation is still low. This is possible because MIN 14 Banjar itself is a school with state status and the majority of teachers at MIN 14 Banjar are civil servants. When viewed from the results of observations and interviews, the facilities at MIN 14 Banjar support innovative learning to make it easier to implement authentic assessments. However, to implement the techniques and instruments for assessing attitudes and knowledge at MIN 14 Banjar, there are still many obstacles, such as the number of students while the time in class is very limited so that it is not sufficient to assess student attitudes and behavior following the educational assessment standards in the curriculum. Limited time in class also affects the teacher in carrying out various kinds of written and oral tests such as making quizzes, tests at the beginning of learning, and others. The obstacles that occur in learning have attempted to solve these obstacles. Both teachers and schools have tried to carry out various activities to improve the quality and quality of teachers in implementing thematic learning according to the 2013 curriculum (Kurnia, 2018). Such as the number of students while the time in class is very limited so that it is not sufficient to assess the attitudes and behavior of students in accordance with the educational assessment standards in the curriculum. Both teachers and schools have tried to carry out various activities to improve the quality and quality of teachers in implementing thematic learning according to the 2013 curriculum (Mawardi, 2014).

The implementation level of authentic assessment at Nur Rahman MIS, Banjar Regency is also in the good category. When viewed from the observed aspects, MIS Nur Rahman Banjar Regency is more dominant in the implementation aspect, while for the technical aspects and the attitude and knowledge assessment instruments, the percentage of implementation is still low. This is possible because the teacher does not have a lot of free time in the classroom to 
enrich knowledge assessment techniques and instruments such as quizzes, tests at the beginning of learning and the end of learning, while attitude assessment only looks at the most prominent ones such as skilled, disciplined, lazy and so on (Puspita, 2016).

From the results of interviews and observations, not only on the technical aspects and knowledge assessment instruments, other aspects also still lack many in implementing authentic assessment ideally. The teacher only makes a very simple lesson plan without being equipped with an assessment rubric and the dominant assessment is written tests such as tests, UAS, and National Examination. And for the assessment of skills itself, it is still very difficult to implement because of very limited costs and time and also students who are still difficult to follow innovative learning such as being invited to discussions, solving problems and others.

Then the results of the relationship between the criteria/identity of the teaching teacher and the level of implementation of authentic assessment in learning are quite influencing, as well as the results of the relationship between the criteria/identity of students and their assessment of the performance of economic teachers in implementing authentic assessments. Based on the analysis, the teachers at MIN 14 Banjar had better implementation levels in the aspects of planning, implementation as well as aspects of analysis and reporting. Teachers of MIN 14 Banjar have better implementation levels in the technical aspects and instruments for assessing attitudes and skills. Then civil servant teachers have better implementation levels in the planning aspect. In the aspects of techniques and instruments for assessing attitudes and skills, non-PNS teachers had slightly better implementation rates.

From the results of observations, documentation, and interviews, MIS Nur Rahman Banjar Regency is more limited with facilities and as a private Madrasah based on a foundation from an Islamic boarding school, so many accesses are lacking such as permits to leave the madrasah or Pondok environment, limited learning time because the number of subjects is very large while the learning time is limited. While at MIN 14 Banjar, the facilities are more complete than the MIS Nur Rahman Banjar Regency. But within MIN 14 Banjar there are also many limitations. Because schools are based on Madrasahs, where many subjects have to be taken in a week, it is difficult for teachers to create innovative learning due to time constraints,

At MIN 14 Banjar, most of the teachers are civil servants. PNS teachers often attend training/education and training regarding the assessment that should be carried out by educators. The weakness in implementing authentic assessment at MIS Nur Rahman Banjar Regency itself is the lack of training/education and training on authentic assessment. Some of the economics teachers at MIS Nur Rahman, Banjar Regency, have never participated in training on authentic assessment, and some of the teachers, even though they have attended the training, still find it difficult to let go of their habit of judging only from written tests. So that in its implementation, the economics teacher who is at MIS Nur Rahman, Banjar Regency still needs to be addressed.

Then, if the PNS teacher is better at the level of implementation in the planning aspect. Whereas in the technical aspects and instrument assessment of attitudes and skills, nonPNS teachers had a slightly better level of implementation. This is possible because PNS teachers have greater demands and better skills than non-PNS teachers. So that in designing PNS teacher planning is better than NonPNS. Regarding the techniques and instruments for assessing attitudes and skills, based on the results of interviews with non-PNS teachers, they have less free time than PNS teachers to prepare and implement skills assessment techniques and instruments.

\section{Obstacles in implementing authentic the- matic learning assessment in 2013 curricu- lum at MIN 14 Banjar and MIS Nur Rahman Banjar Regency}

In the 2013 Curriculum, the assessment that educators should use is authentic assessment. The authentic assessment itself does require teachers to make innovative learning. Because with innovative learning, teachers can 
use a variety of authentic assessment techniques and instruments such as performance appraisals, projects, portfolios, and others. With this demand, MIN 14 Banjar teachers and MIS Nur Rahman Banjar District still experience many obstacles in implementing authentic ideal assessments according to educational assessment standards.

One of the obstacles for MIN 14 Banjar teachers in Banjar Regency that needs to be triangulated is the lack of student motivation to take innovative learning. The triangulation results of the validity of the data regarding the teacher's opinion on these constraints, which occurred in the aspects of the implementation of authentic assessments and the technical aspects and skills assessment instruments were also supported by the results of interviews with students and the curriculum section regarding teacher performance in innovative learning (Wajdi, 2017).

The results of an interview with the MIS teacher Nur Rahman, Banjar Regency, stated that sometimes it was difficult for students to be given learning which required students to find the subject matter themselves as an assignment. Sometimes there are still many students who don't understand the material that the teacher has delivered. Furthermore, the teacher concerned also stated that students were more pleased with learning as usual, namely the lecture method. This is because if the teacher gives an assignment, sometimes students feel lazy, complicated, and difficult if given an assignment that requires students to find their source of subject matter such as books, the internet or newspapers.

From the results of interviews with MIN 14 Banjar teachers and MIS Nur Rahman, Banjar Regency regarding the obstacles in implementing authentic assessments in economic learning, including for the planning aspect, the obstacles faced are quite a lot of time to make good and correct RPP following educational assessment standards it is in the curriculum, so that when there is no free time the lesson plans are made short or use the lesson plans of the previous school year. Then the number of criteria/assessment components that must be planned in an authentic assessment and in determining indicators and making rubrics is still difficult to do because it is not familiar and takes time to make. So seeing the number of components/criteria for authentic assessment and having to determine the indicators or rubrics, the teacher feels a lot of time-consuming, while other work is still piling up. This is the basic obstacle for MIN 14 Banjar and MIS Nur Rahman teachers in Banjar Regency in the aspect of authentic assessment planning. This is also supported by the results of (Taufina \& Chandra, 2017) research on authentic assessment evaluations, which states that authentic assessment planning is too complicated to make.

The obstacle faced by teachers of MIN 14 Banjar and MIS Nur Rahman in Banjar Regency in the implementation aspect is the difficulty in changing habits with traditional assessments to be authentic. This means that sometimes teachers already know that authentic assessment is ideally very good if it is implemented in learning, but in its implementation in the classroom, it is very difficult because there are too many things to do in class, making the teacher come back to do traditional assessment simpler and already used to doing it. The number of components that teachers pay attention to simultaneously during the implementation of the assessment is an obstacle for MIN 14 Banjar teachers and MIS Nur Rahman Banjar Regency in implementing it.

Then the lack of student motivation in innovative learning, so that authentic assessment is difficult to carry out (Widiatsih et al., 2020). So, when teachers make innovative learning such as given group assignments or individual assignments to observe a market, company or other, students are sometimes not serious in doing it. So that the teacher feels that it is only a waste of time if innovative learning continues. This is supported by the results of an interview with the curriculum section which states that sometimes it is difficult for students to be given learning which requires students to find the subject matter themselves as an assignment. Sometimes there are still many students who don't understand the material that the teacher has delivered.

The results of interviews with the teacher also stated that students were more pleased with learning as usual, namely the lecture 
method. This is because if the teacher gives an assignment, sometimes students feel lazy, complicated, and difficult if given an assignment that requires students to find their source of subject matter such as books, the internet, or newspapers. From the several interviews it can be drawn the middle line that when the teacher makes innovative learning but is not supported by madrasah facilities, as well as when the teacher designs innovative learning, it is possible that the delivery is not good enough so that it makes students feel confused or unclear. Furthermore, in the implementation of authentic assessment, constraints can be seen from the technical aspects and assessment instruments for attitudes, knowledge, and skills.

The obstacles faced by teachers of MIN 14 Banjar and MIS Nur Rahman, Banjar Regency in the aspects of technique and attitude assessment instruments are too many components in the attitude assessment, so it takes a lot of time if the attitude assessment is carried out ideally according to the educational assessment standards in the curriculum. Then the teacher finds it very difficult if they have to assess in detail the behavior and attitudes of students simultaneously, while the capacity of students, in general, is still very large. The obstacle for MIN 14 Banjar and MIS Nur Rahman teachers in Banjar Regency for attitude assessment is that they must pay attention to students in detail with a large number of students.

Attitude competence is often an obstacle for teachers, teachers find it very difficult if they have to simultaneously assess what is in each student (Alpiyanto et al., 2012). Sometimes teachers also feel sorry for students if they have to judge according to the behavior of these students, because at the age of elementary school they still like to play, so the behavior/attitudes of students must be good according to the demands of the rubric, it is very difficult If implemented ideally, the results are many students whose value is disturbed by the results of the attitude assessment. This is what makes the teacher finally judge as a whole as the best, the sharpest, and the laziest.

The obstacles faced by MIN 14 Banjar and MIS Nur Rahman teachers in Banjar Regency in

JK6EM | Journal of K6 Education and Management the technical aspects and knowledge assessment instruments were for assessments other than tests, UAS and UN took time during learning, so they did not have time to carry out such as assignments, question and answer, quizzes, initial tests or at the end of learning and other forms of cognitive testing. This causes the teacher to end up using only multiple-choice tests and essays in implementing knowledge assessments.

The obstacles faced by teachers of MIN 14 Banjar and MIS Nur Rahman of Banjar Regency in the technical aspects and skills assessment instruments were the lack of student motivation, inadequate cost and time, madrasah facilities, and limited permits for observation outside the madrasah. This makes it difficult for teachers to implement a variety of skills assessment techniques and instruments. The teacher only implements skills assessment techniques and instruments that are easy to implement, such as setting up discussion groups and observations to madrasah cooperatives.

Then from the results of the interview, for analysis and reporting, it is not too difficult to implement, because everything is left to the madrasah curriculum section. But in submitting the assessment documentation, the teacher also found many obstacles, including the obstacles faced by MIN 14 Banjar teachers and MIS Nur Rahman Banjar Regency in the aspect of analysis and reporting, namely the number of instruments that took time to describe and it was difficult to make conclusions, the amount of documentation was lost so that it is a little difficult to describe the assessment and some teachers still use report cards which are only numbers and a brief description.

\section{Solutions to Overcome Obstacles in Imple- menting Authentic Assessment of Thematic Learning in the 2013 Curriculum at MIN 14 Banjar and MIS Nur Rahman Banjar Regency}

The results showed that there were some obstacles in the implementation of authentic assessment of thematic learning in the 2013 curriculum at MIN 14 Banjar and MIS Nur Rahman Banjar Regency, starting from the aspects of planning, implementation to analysis and reporting of authentic assessments. To overcome the constraints on the aspects of 
authentic assessment planning caused by taking too much time when making assessment planning in the RPP, many criteria/assessment components must be planned in an authentic assessment, and determining indicators and making rubrics is still difficult to do, because they are not familiar and time-consuming to manufacture. Can be overcome by forming a group of teachers in which to discuss planning authentic assessment. Through this teacher working group, it is hoped that the teachers who are members will find it easier and faster to make authentic assessment plans.

This solution has been implemented by each madrasah, by participating in teacher group activities, namely KKG for PNS teachers and GMPP (Student Care for Education Movement) which is the majority teacher group at MIS Nur Rahman who has a background from students majoring in Islamic Religious Education (PAI) at STAI. Although it is still not done often, it still needs to deepen these activities so that the obstacles that occur can be resolved and teachers can fulfill the aspects of planning for authentic assessment of thematic learning in their respective classes.

Constraints from the aspect of implementing authentic assessment are caused by several things, namely: difficulty changing habits with traditional assessments to be authentic and student motivation who is still lacking in innovative learning, so that authentic assessments are difficult to carry out. This obstacle can be overcome by getting the teacher accustomed to doing authentic assessments, besides that it can also be overcome by increasing the number of meetings with other teachers who also apply authentic assessments to discuss various aspects related to the implementation of authentic assessments. Through this method, it is hoped that teachers will get used to the implementation of authentic assessments more quickly.

This solution is also included in the teacher group activities that have been implemented. Although there are still several aspects of the assessment that are still incompletely implemented, according to the authentic assessment model which consists of skills domains, in this case, performance appraisal, project appraisal, and product appraisal, and portfolio assessment. Then in the realm of attitude that is still done by peer assessment and peer assessment which is still rarely done. Many teachers still rely on assessments through teacher journals. And the realm of knowledge that has been carried out in written tests, observations, and assignments.

The constraints for authentic assessment of attitude assessment techniques and instruments are caused by too many components in attitude assessment, it takes a lot of time if the attitude assessment is done ideally following the demands of the curriculum, and the teacher must assess in detail the behavior and attitudes of students simultaneously, while the capacity of students, in general, there are still very many. This problem that becomes an obstacle can be overcome by involving teachers in training based on increasing the ability of teachers in carrying out authentic assessments. Through this method, it is hoped that the teacher's ability to carry out authentic assessments can increase so that teachers no longer think that there are too many components in the attitude assessment and can carry out an ideal attitude assessment.

This solution has also been carried out in teacher group activities at each madrasah. There is still little formal training under the Ministry of Religion, but it is enough to help madrasah teachers to learn the techniques and instruments for attitude assessment used in carrying out an authentic assessment of thematic learning in the 2013 curriculum.

For MIN 14 Banjar teachers, this activity is often carried out under the auspices of the ministry of religion, because many of the teachers are civil servants of the Ministry of Religion, so there is already an agenda for each of these teachers. Whereas for Nur Rahman's MIS teachers, who are mostly honorarium teachers and foundation teachers, training and coaching are carried out following the GMPP's suggestion to schools to carry out training by finding their resource persons and implementing them specifically in the Nur Rahman madrasah environment. This activity is usually carried out every year during the Ramadan holidays. However, due to the pandemic that was hitting this 
year, the training activities at MIS Nur Rahman this year were not carried out. So that researchers only see differences in documents in previous years,

Problems that become obstacles in the implementation of authentic assessments, especially in the technical aspects and knowledge assessment instruments, are because assessments such as making quizzes, pre and post-tests, and other assessment techniques often fail to be implemented due to time constraints. This can be overcome by the way the teacher prepares instruments in the form of quizzes, pre-tests, and post-tests, and other assessment techniques, for example, having prepared everything during semester breaks, so that when it comes to school and it's time for authentic assessment, the teacher just needs to apply the instrument. which was created before. In this way, there will be no more constraints caused by time constraints.

This solution has also been carried out in teacher group activities at each madrasah. There is still little formal training under the Ministry of Religion, but it is enough to help madrasah teachers to learn the techniques and instruments for assessing knowledge used in carrying out an authentic assessment of thematic learning in the 2013 curriculum.

Obstacles in carrying out authentic assessments, especially in the aspects of techniques and skills assessment instruments, are caused by several things, namely: Lack of student motivation in doing assignments, consuming a lot of money and time, and Madrasah facilities, as well as limited permits for observations outside the madrasah. This obstacle can be overcome by motivating students to be able to carry out tasks quickly and precisely, in addition to madrasah facilities which are deemed insufficient to be overcome by making improvements and adding madrasah facilities which can be done by submitting an application to the foundation or the Ministry of Religion to immediately adding madrasa facilities that are still lacking.

This solution has also been carried out in teacher group activities at each madrasah. There is still a small number of formal training under the Ministry of Religion, but it is enough to help madrasah teachers to learn the techniques and instruments for assessing skills used in carrying out an authentic assessment of thematic learning in the 2013 curriculum.

Obstacles in implementing authentic assessments, especially in the analysis and reporting aspects of authentic assessments, are caused by several things, namely: the number of instruments that take time to describe and make conclusions difficult, a large amount of documentation is missing so that the teacher finds it difficult to describe the assessment, and still uses report cards which are only numbers and a brief description. This obstacle can be overcome by preparing the instruments well before the learning process begins, for example during the holidays. The teacher should also prepare a folder that is devoted to storing assessment document files so that it is easier to use them again.

In this constraint and solution, it is the school that plays a role in helping teachers prepare equipment so that the documents used in the authentic assessment of thematic learning to analyze and report the results of implementing learning activities in authentic assessment can be done better and neatly.

For MIN 14 Banjar teachers, they already have sufficient equipment in reporting the assessment results, while for MIS Nur Rahman teachers is also quite adequate, although some teachers have to prepare with their funds.

\section{Conclusion and Recommendation}

Teachers of MIN 14 Banjar and MIS Nur Rahman of Banjar Regency have carried out authentic assessments properly in the thematic learning of Curriculum 13 because the assessment is carried out on aspects, namely the assessment of attitudes, knowledge, and skills. Attitude competency assessment uses observations, journals, and assessments among students, knowledge competency assessments use written tests, oral tests and assignments, while skills competency assessments are carried out through performance appraisals, project, and portfolio assessments.

Obstacles in Implementing Authentic Thematic Learning Assessment in the 2013 Curriculum at MIN 14 Banjar and MIS Nur Rahman 
Banjar Regency, namely: limited time constraints, higher costs, the number of components/criteria in authentic assessment, the lack of motivation of students in participating in innovative learning with authentic assessments and limited madrasah facilities and infrastructure.

The solution to overcome the obstacles in implementing authentic thematic learning assessments in the 2013 Curriculum at MIN 14 Banjar and MIS Nur Rahman Banjar Regency. Constraints in the planning aspect can be overcome byform a group of teachers in which they are devoted to discussing authentic assessment planning. Through this teacher working group it is hoped that the teachers who are members will find it easier and faster in making authentic assessment plans, obstacles in the implementation aspects of authentic assessments can be overcome by familiarizing the teacher to carry out authentic assessments, besides that it can also be overcome by increasing the number of meetings with other teachers who also apply authentic assessment to discuss various aspects related to the implementation of authentic assessments. Constraints in the technical aspects and attitude assessment instruments can be overcome by involving teachers in training based on increasing the ability of teachers in carrying out authentic assessments. Constraints in the technical aspects and knowledge assessment instruments can be overcome by the way the teacher prepares instruments in the form of quizzes, pre-tests and post-tests, and other assessment techniques, for example, having prepared everything during semester breaks, so that when entering school and it's time to carry out an authentic assessment, the teacher just needs to apply the previously made instruments. Constraints in the technical aspects and knowledge assessment instruments can be overcome by motivating students to be able to carry out assignments quickly and accurately, Also, madrasah facilities that are deemed insufficient can be resolved by making improvements and adding madrasah facilities, which can be done by submitting a request to the foundation or the Ministry of Religion to immediately add insufficient madrasah facilities. Constraints in the analysis and reporting aspects of authentic assessment can be overcome by preparing the instruments well in advance of the learning process, for example during the holidays. It is better if the teacher also prepares a folder that is devoted to storing assessment document files so that it is easier to reuse them. Constraints in the analysis and reporting aspects of authentic assessment can be overcome by preparing the instruments well in advance of the learning process, for example during the holidays. It is better if the teacher also prepares a folder that is devoted to storing assessment document files so that it is easier to reuse them. Constraints in the analysis and reporting aspects of authentic assessment can be overcome by preparing the instruments well in advance of the learning process, for example during the holidays. It is better if the teacher also prepares a folder that is devoted to storing assessment document files so that it is easier to use them again.

\section{Acknowledgment}

The researcher realized that this research could be finished because of the help of others, directly or indirectly. Therefore, the researcher was very thankful for all people who had helped in finishing this research.

\section{References}

Aiken, L. R. (1996). Tests Psicologicosy Evaluacion. Mexico: Prentice Hall.

Alpiyanto, Hamda, S., \& Dalle, J. (2012). The role of teachers in the formation of student characters through local visition. Prosiding Temu Ilmiah Nasional Guru IV (pp. 74-83). Jakarta: Open University.

Amod, Z., \& Heafield, D. (2013). School readiness assessment in South Africa. In Laher S. \& Cockcroft K. (Eds.), Psychological Assessment in South Africa: Research and applications (pp. 74-85). Johannesburg, South Africa: Wits University Press. Atkinson, J. (2017). Qualitative Methods. In Journey into Social Activism: Qualitative Approaches (pp. 65-98). New York: Fordham University Press.

Behar, L. (1994). An Empirical Analysis of Curriculum Domains: Implications for Program Development and Evaluation. Peabody Journal of Education, 69(4), 100-112.

Beuchamp, G. (1961). Curriculum Theory. Wilmete, IL: Kagg Press.

Boud, D., \& Falchikov, N. (2006). Aligning assessment with longterm learning. Assessment \& Evaluation in Higher Education, 31(4), 399-413. 
Brown, J. S., Collins, A., \& Duguid, P. (1989). Situated cognition and the culture of learning. Educational researcher, 18(1), $32-42$

Condemarin, M., \& Medina, A. (2000). Evaluacion Autentica de los Aprendizajes: Uh medio para majorar las competencias en lenguaje y comunicacion. Santiago de Chile: Editorial Andres Bello.

Dalle, J., \& Mutalib, A. A. (2018). The impact of technologies in teaching interaction design. Journal of Advanced Research in Dynamical and Control Systems, 4(special issue), 1779. 1783.

Enggarwati, N. (2015). Kesulitan Guru SD Negeri Glagah Dalam Mengimplementasikan Penilaian Autentik Pada Kurikulum 2013. Basic Education, 5(12).

Foshay, A., \& Beilin, L. A. (1969). Curriculum. In the Encyclopedia of educational research (2nd ed.) (pp. 275-178). New York: MacMillan.

Fung, D. (2017). Introducing the Connected Curriculum framework. In Connected Curriculum for Higher Education (pp. 4-19). London: UCL Press.

Green, F. (2019). An Exploration into the Value of Formative Assessment and the Barriers Associated with the Implementation of Formative Strategies. In K.-W. M., K.-B. A., D. W., \& \&. L. (Eds.), Rethinking Teacher Education for the 21st Century: Trends, Challenges and New Directions (pp. 203-222). Opladen; Berlin; Toronto: Verlag Barbara Budrich.

Gulikers, J. T., Bastiaens, T. J., \& Kirschner, P. A. (2004). A fivedimensional framework for authentic assessment. Educational Technology Research and Development, 52(3), 67-86.

Herrington, J., \& Herrington, A. (1998). How university students respond to a model of authentic assessment. Higher Education Research and Development, 17(3), 305-322.

Kanjee, A. (2013). Large-scale assessment studies in South Africa: Trends in reporting results to schools. In Laher S. \& Cockcroft K. (Eds.), Psychological Assessment in South Africa: Research and applications (pp. 516-534). Johannesburg, South Africa: Wits University Press.

Kiernan, P. J., \& Aizawa, K. (2004). Cell phones in task based learning -Are cell phones useful language learning tools? ReCALL, 16(01), 71-84.

Kneale, P. E., \& Collings, J. (2015). Developing and embedding inclusive assessment: issues and opportunities. In Ped RIO paper7: Inclusive Assessment. Plymouth University.

Kneale, P., \& Collings, J. (2018). Towards inclusive assessment: The journey at the University of Plymouth. In AuferkorteMichaelis N. \& Linde F. (Eds.), Diversität lernen und lehren - ein Hochschulbuch (pp. 31-43). Opladen; Berlin; Toronto: Verlag Barbara Budrich.
Kurnia, I. S. (2018). Implementasi Pembelajaran Tematik Di Lima SD Swasta Wilayah DKI Jakarta. Jurnal Perkotaan, 10(2), 127-146.

Kusmijati, N. (2014). Penerapan Penilaian Autentik Sebagai Upaya Memotivasi Belajar Peserta Didik. Seminar Nasional LPP. Purwokerto.

Laborda, J. G., Sampson, D. G., \& Guzman, E. (2015). Guest Editorial: Technology Supported Assessment in Formal and Informal Learning. Journal of Educational Technology \& Society, 18(2), 1-2.

Mawardi, M. (2014). Pemberlakuan Kurikulum SD/MI Tahun 2013 Dan Implikasinya Terhadap Upaya Memperbaiki Proses Pembelajaran Melalui PTK. Scholaria: Jurnal Pendidikan Dan Kebudayaan, 4(3), 107-121.

Olfos, R., \& Zulantay, H. (2007). Reliability and Validity of Authentic Assessment in a Web Based Course. Journal of Educational Technology \& Society, 10(4), 156-173.

Ornstein, A. C. (1993). Curriculum: Foundations, principles and issues (2nd ed.). Boston: Allyn \& Bacon.

Osman, R. (2013). Assessment of prior learning: A South African perspective. In Laher S. \& Cockcroft K. (Eds.), Psychological Assessment in South Africa: Research and applications (pp. 509-515). Johannesburg, South Africa: Wits University Press.

Puspita, H. (2016). Implementasi Pembelajaran Tematik Terpadu Pada Kelas Vb SD Negeri Tegalrejo 1 Yogyakarta. BASIC EDUCATION, 5(9), 884-893.

Rosales-Dordelly, C. L., \& Short, E. (1985). Curriculum professors specialized knowledge. Lanham, MD: University of America Press.

Santos, P., Cook, J., \& Hernandez-Leo, D. (2015). M-AssIST: Interaction and Scaffolding Matters in Authentic Assessment. Journal of Educational Technology \& Society, 18(2), 33-45.

Shadiev, R., Hwang, W. Y., \& Huang, Y. M. (2017). Review of research on mobile language learning in authentic environments. Computer Assisted Language Learning, 30(3-4), 284-303.

Shadiev, R., Hwang, W., Ghinea, G., \& Chang, M. (2018). Guest Editorial: Authentic Edutainment with Advanced Technologies. Journal of Educational Technology \& Society, 21(4), 111-114.

Taufina, T., \& Chandra, C. (2017). The Implication of Authentic Assessment in Thematic Integrated Learning Process at Lower Level Elementary School Early Childhood Development. International Conference of Early Childhood Education (ICECE 2017). Atlantis Press.

Wajdi, F. (2017). Implementasi Project Based Learning (PBL) Dan Penilaian Autentik Dalam Pembelajaran Drama Indonesia. Jurnal Pendidikan Bahasa Dan Sastra UPI, 17(1), 86-101. 
I Huda, 2020 / Implementation of authentic assessment in thematic learning 2013 curriculum at Madrasah Ibtidaiyah

Widiatsih, A., Wulandari, R., \& Muarif, S. (2020). Pemanfaatan Google Classroom Dalam Penilaian Autentik Studi Kasus
SD Negeri Sidomulyo 05 Silo Kabupaten Jember. Rekayasa, 13(2), 187-196. 